\title{
Multiple Brain Abscesses Caused by Fusobacterium nucleatum Treated Conservatively
}

\author{
Josef G. Heckmann, Christoph J.G. Lang, Heinz Hartl, Bernd Tomandl
}

\begin{abstract}
Background: Multiple brain abscesses are serious neurological problems with high mortality and disabling morbidity. The frequency is rising as a result of AIDS and the increasing number of immunocompromised patients. Case study: A 59-year-old woman developed signs and symptoms of diffuse brain dysfunction including fever and neck stiffness. A brain CT scan demonstrated nine contrast-enhancing ring-shaped lesions. Analysis of the cerebrospinal fluid using PCR-technique revealed DNA of Fusobacterium nucleatum. Conservative treatment with antibiotics was successful. The patient recovered with only mild cognitive deficits. Results: The experience of our patient and the review of the literature indicate that multiple brain abscesses due to Fusobacterium nucleatum are rare. The most probable source is oral infection. Conclusion: Multiple brain abscesses may be caused by Fusobacterium nucleatum. Cerebrospinal fluid analysis using PCR technique is helpful with diagnosis. Conservative management can be successful.
\end{abstract}

RÉSUMÉ: Traitement conservateur des abcès cérébraux multiples causés par Fusobacterium nucleatum. Introduction: Les abcès cérébraux multiples constituent toujours un problème neurologique sérieux comportant un taux de mortalité élevé et une morbidité sévère. Leur fréquence augmente dans le contexte de l'épidémie du SIDA et du nombre croissant de patients immunocompromis. Étude de cas: Une femme âgée de 59 ans a présenté des signes de dysfonction cérébrale diffuse accompagnés d'hyperthermie et de raideur de la nuque. La tomodensitométrie cérébrale a mis en évidence la présence de neuf lésions annulaires rehaussantes. L'analyse du liquide céphalo-rachidien (LCR) au moyen de la technique de l'amplification en chaîne par polymérase (PCR) a révélé la présence d'ADN du Fusobacterium nucleatum. Le traitement conservateur par antibiotiques a été efficace et la patiente ne présentait comme séquelle que de légers déficits cognitifs. Résultats: Ce cas ainsi que la revue de la littérature indiquent que les abcès cérébraux multiples dus au Fusobacterium nucleatum sont rares. La source d'infection la plus probable est une infection orale. Conclusions: Des abcès cérébraux multiples peuvent être causés par le Fusobacterium nucleatum. L'analyse du LCR par la technique de la PCR peut aider au diagnostic. Le traitement conservateur peut être efficace.

Can. J. Neurol. Sci. 2003; 30: 266-268

Brain abscesses are less common than brain tumours, but their frequency has increased over the past decade as a result of AIDS and a rising number of immunocompromised patients. ${ }^{1,2}$ Abscesses are usually solitary in the frontal or parietal lobe, of variable size, and develop by contagious spread. Multiple abscesses are usually related to pulmonary and dental infections and arise from hematogeneous dissemination. ${ }^{1}$ Multiple abscesses are serious neurological problems with high mortality and disabling morbidity in survivors. ${ }^{3,4}$ The causative pathogens of bacterial brain abscess vary with geographic distribution, age, underlying medical and surgical conditions and mode of infection. ${ }^{4}$ Reports on brain or spinal abscesses caused by Fusobacterium nucleatum are uncommon. ${ }^{4-6}$ Recently, we cared for a patient with multiple brain abscesses due to Fusobacterium nucleatum and conservative treatment resulted in clinical recovery with only mild cognitive deficits.

\section{CASE REPORT}

A 59-year-old woman was found confused in her home. There was a history of moderate ethanol (three cans of beer a day) use. On admission

From the Deptartments of Neurology (JGH, CJGL, HH) and Neuroradiology (BT), University Hospital, Erlangen-Nuremberg, Germany.

Received August 20, 2002. AcCePted in Final Form December 9, 2002. Reprint requests to: Josef G. Heckmann, Dept. of Neurology, University Hospital Erlangen-Nuremberg, Schwabachanlage 6, 91054 Erlangen, Germany 


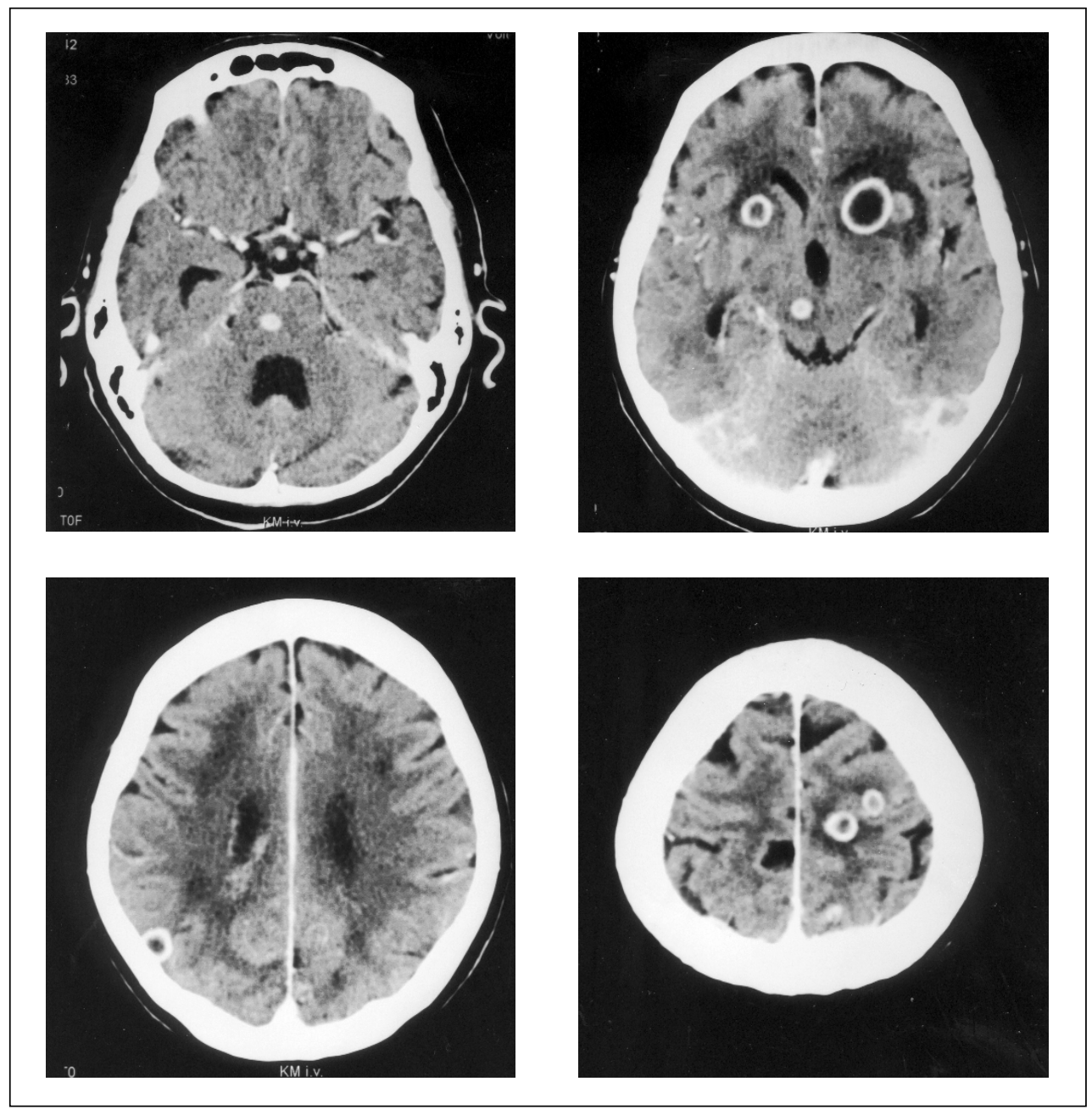

Figure: Axial contrast enhanced CT demonstrates multiple ring-enhancing lesions.

she was disorientated and suffering from marked neck stiffness. Her body temperature had risen to $38.7^{\circ} \mathrm{C}$. The neurological examination did not show focal abnormalities. Contrast enhanced computed tomography (CT) of the head (Figure) revealed nine ring-shaped enhancing lesions.

Lumbar puncture showed granulocytic pleocytosis $(32,000$ white cells/cu mm; normal <4), elevated protein $(5.98 \mathrm{~g} / \mathrm{L}$; normal $<0.5 \mathrm{~g} / \mathrm{L})$, elevated lactate $(15 \mathrm{mmol} / \mathrm{L}$; normal $1.1-2.1 \mathrm{mmol} / \mathrm{L})$ and decreased glucose $(<1 \%$, normal $>40 \%)$. Microbiological studies of the CSF using PCR technique demonstrated DNA of Fusobacterium nucleatum. Blood and CSF cultures were negative. The only predisposing factor in the patient's history was moderate alcohol consumption. Tests for diabetes mellitus and HIV infection were negative. Ceftriaxon $2 \mathrm{~g} /$ daily, fosfomycin $3 \times 3 \mathrm{~g} /$ daily and metronidazol $3 \times 0.5 \mathrm{~g} /$ daily were administered for four weeks. In addition, dexamethasone ( $3 \times 3 \mathrm{~g} /$ daily) was administered to treat brain edema for ten days. Neurosurgical stereotactic aspiration and drainage was discussed initially but discarded because of rapid neurological clinical improvement. Transesophageal echocardiography, CT of thorax and abdomen and otolaryngeal consultation did not show any source of infection. Dental examination revealed a poor dental hygiene but there were no recent dental infections. The patient improved but intercurrent nosocomial bronchopneumonia required ciprofloxacin $(2 \times 0.4 \mathrm{~g} /$ daily for ten days) and transient mechanical ventilation for four days. The patient later received rehabilitation and recovered with only mild cognitive deficits (impaired attention and memory).

\section{Discussion}

Despite the demarcation of nine abscesses on the CT scan, including one prominent one in the brainstem, our patient showed only signs and symptoms of diffuse brain dysfunction and no focal neurological deficits. Thus, only two of the typical triad $^{1}$ (headache, fever, focal neurologic dysfunction) were present. Further differential diagnosis for multiple ring-shaped enhancing lesions includes primary and secondary tumors, other infectious etiologies such as fungal and parasitic infections, resolving cerebral hemorrhage, radiation necrosis, granulomatous processes and inflammatory demyelinating diseases (see Table). ${ }^{7,8}$ These were excluded in our patient by history and adjuvant laboratory studies.

Microbiological cultures of the CSF and blood were negative. 
Table: Differential diagnosis of multiple brain abscesses (modified from Grumme et al, ${ }^{7}$ Solbrig et al, ${ }^{8}$ and Roda et al. ${ }^{19}$ )

\section{Differential diagnosis}

Abscesses / multiple abscesses

Other infectious etiologies which mimic multiple abscesses

Primary or metastatic brain tumours (e.g. glioblastoma, lymphoma)

Encapsulated hematoma

Granulomas

Radiation necrosis

Demyelinating diseases

\section{Notations / CT-findings}

Space-occupying, perifocal edema, mostly with small contrast enhancing ring, ring of enhancement often thicker near the cortex and thinner near the ventricle, blood-borne abscesses often found at grey and white matter junctions in the territory of the middle cerebral artery

Subdural empyema, epidural abscess, viral encephalitis, bacterial or acute aseptic meningitis, endocarditis with septic embolism, fungal and parasitic infections

Space-occupying, perifocal edema, mostly with broad contrast enhancing ring

Encapsulated hematoma with ring of contrast enhancement and perifocal edema usually caused by vascular malformation

Tuberculoma, gumma, sarcoidosis

History of radiation

Tumour-like lesion with enhancement in multiple sclerosis (MS) or in progressive multifocal leukoencephalopathy
Using PCR, DNA of anaerobic Fusobacterium nucleatum was identified as the most probable causative organims in CSF. Anaerobic isolates are encountered with increasing frequency, but solitary Fusobacterium nucleatum is rarely identified., ${ }^{1,5,9}$ Despite this, we did not find the infectious source and assumed that there was an underlying orofacial infection, due to the poor dental health of the patient. Fusobacterium nucleatum belongs to the family of Bacteroidaceae. The term is derived from the Latin word fusus, referring to its spindle-shaped appearance. The germ is nonsporeforming, nonmotile, gram-negative and mainly anaerobic. ${ }^{10}$ Its pathogenic potential has gained significance in the development of periodontal diseases and, in particular, in orofacial infections. ${ }^{10,11}$ Infection of other organs such as liver, lung, heart and central nervous system caused by Fusobacterium nucleatum are very rare. .,6,11-14 $^{-1}$

Conservative treatment in our patient using antibiotics and steroids was successful. Nevertheless the optimal treatment of brain abscesses is still a matter for debate. Proposed treatment regimens are either antibiotics alone or in combination with stereotactic aspiration and craniotomy for excision. ${ }^{15}$ The general consensus has been that solitary abscesses, that can be safely approached neurosurgically should be treated stereotactically with aspiration, possibly combined with drainage and systemic antibiotics.,15-17 Multiple abscesses, small abscesses, early stage of cerebritis or abscesses in an unfavourable location warrant conservative treatment perhaps combined with stereotactic drainage and to identify the causative organism. ${ }^{15,18}$

\section{REFERENCES}

1. Case 43-1993. N Engl J Med 1993;329:1335-1341.

2. Calfee DP, Wispelwey B. Brain abscess. Semin Neurol 2000;20:353-360.

3. Sotelo J. Commentary on the article - Mutiple brain abscesses caused by Salmonella typhi: case report. Surg Neurol 2000;53:86-90.

4. $\mathrm{Lu} \mathrm{CH}$, Chang $\mathrm{WN}$, Lin $\mathrm{YC}$, et al. Bacterial brain abscess: microbiological features, epidemiological trends and therapeutic outcomes. Q J Med 2002;95:501-509.
5. Taguchi Y, Sato J, Nakamura N. Gas-containing brain abscess due to Fusobacterium nucleatum. Surg Neurol 1981;16:408-410.

6. Recagno G, Borda N, Placenzotti C, Jairala D, Notario R. Spinal epidural abscess due to Fusobacterium nucleatum. Medicina (B Aires) 1997;57:720-722. [in Spanish]

7. Grumme T, Kluge W, Kretzschmar K, Roesler A. Zerebrale und Spinale Computertomographie. Berlin Wien: Blackwell Wissenschafts-Verlag, 1998. [in German]

8. Solbrig MV, Healy JF, Jay CA. Bacterial infections. In: Bradley WG, Daroff RB, Fenichel GM, Marsden CD, (Eds). Neurology in Clinical Practice, third ed. Boston: Butterworth Heinemann, 2000: 1317-1351.

9. Chaudry R, Dhawan B, Laxmi BV, Mehta VS. The microbial spectrum of brain abscesses with special reference to anaerobic bacteria. Br J Neurosurg 1998;12:127-130.

10. Bolstad AI, Jensen HB, Bakken V. Taxonomy, biology, and periodontal aspects of Fusobacterium nucleatum. Clin Microbiol Rev 1996;9:55-71.

11. Roberts GL. Fusobacterium infections: an underestimated threat. $\mathrm{Br}$ J Biomed Sci 2000;57:156-162.

12. Memain N, Arvaniti K, Bruneel F, et al. Septic shock with liver abscess in an immunocompetent patient. Presentation of an unusual Fusobacterium nucleatum infection. Presse Med 2001;30:1777-1779. [in French]

13. Brook I. Clinical review: bacteremia caused by anaerobic bacteria in children. Crit Care 2002;6:205-211.

14. Shammas NW, Murphy GW, Eichelberger J, et al. Infective endocarditis due to Fusobacterium nucleatum: case report and review of the literature. Clin Cardiol 1993;16:72-75.

15. Shahzadi S, Lozano AM, Bernstein M, Guha A, Tasker RR. Stereotactic management of bacterial brain abscesses. Can J Neurol Sci 1996;23:343-349.

16. Schielke E. Bacterial brain abscess. Nervenarzt 1995;66:745-753. [in German]

17. Bidzinski J, Koszewski W. The value of different methods of treatment of brain abscess in the CT era. Acta Neurochir (Wien) 1990;105:117-120.

18. Wispelwey B. Brain abscesses. In: Mandell GL, Bleck TP, (Eds). Atlas of Infectious Diseases, Volume III, Central Nervous System and Eye Infections. Philadelphia: Churchill Livingstone, 1995: 4.1-4.16.

19. Roda JM, Carceller F, Perez-Higueras A, Morales C. Encapsulated intracerebral hematomas: a defined entity. Case report. J Neurosurg. 1993;78:829-833. 